\title{
Physicochemical Changes of Deep-Fat-Fried Chicken Drumsticks Treated with Quercetin-in-Edible Coating during Storage Time
}

\author{
Kelvin Adrah ${ }^{1}$, Daniel Ananey-Obiri ${ }^{2}{ }^{(1)}$ and Reza Tahergorabi ${ }^{1, *}$ (]) \\ 1 Food and Nutritional Sciences Program, North Carolina Agricultural and Technical State University, \\ Greensboro, NC 27411, USA; kadrah@aggies.ncat.edu \\ 2 Department of Computational Sciences and Engineering, College of Engineering, North Carolina Agricultural \\ and Technical State University, Greensboro, NC 27411, USA; dananeyobiri@aggies.ncat.edu \\ * Correspondence: rtahergo@ncat.edu; Tel.: +1-(336)-285-4865
}

Citation: Adrah, K.; Ananey-Obiri, D.; Tahergorabi, R. Physicochemical Changes of Deep-Fat-Fried Chicken Drumsticks Treated with Quercetin-in-Edible Coating during Storage Time. Foods 2021, 10, 467. https://doi.org/10.3390/ foods10020467

Academic Editor: Qin Wang

Received: 1 February 2021

Accepted: 18 February 2021

Published: 20 February 2021

Publisher's Note: MDPI stays neutral with regard to jurisdictional claims in published maps and institutional affiliations.

Copyright: (c) 2021 by the authors. Licensee MDPI, Basel, Switzerland. This article is an open access article distributed under the terms and conditions of the Creative Commons Attribution (CC BY) license (https:// creativecommons.org/licenses/by/ $4.0 /)$.

\begin{abstract}
In this study, $10 \%$ of chicken protein isolate (CPI) and quercetin (1 mg/mL) were used to develop an edible coating to improve the oxidative stability of deep-fat-fried chicken drumsticks during refrigerated storage $\left(4^{\circ} \mathrm{C}\right)$ for 10 days. Chicken samples with edible coating formulated with only $10 \%$ CPI served as the control. Although the thiobarbituric acid reactive substances (TBARS) values of the treated samples were lower than the control samples, no significant differences were observed. Quercetin-treated samples were generally harder than control samples. The $\mathrm{pH}$ was reduced by quercetin incorporation $(p<0.05)$. $L^{*}$ and $b^{*}$ values increased, while there was no significant variation in $a^{*}$ values during storage $(p>0.05)$.
\end{abstract}

Keywords: quercetin; edible coating; deep-fry; chicken; oxidation; quality

\section{Introduction}

Several studies evidenced that oils used in deep-fat frying are absorbed by the food and increase the total fat content [1-3]. Consequently, overconsumption of fried foods may lead to obesity, type 2 diabetes, and cardiovascular disease, to name a few. Cardiovascular disease represents the leading cause of death and it is estimated that more than 23.6 million people will die from this by 2030 [4].

About two decades ago, it was suggested that an edible coating is capable of reducing moisture loss and further reducing fat uptake in fried foods [5]. The edible coating can be prepared from different materials or by combining several compounds which are formed on the surface of food products. However, protein-based films gained interest due to their superior mechanical properties. Our previous research showed that the application of an edible coating prepared from protein recovered from fish and chicken processing byproducts results in a significant reduction in fat uptake in deep-fat-fried products [6,7].

Although fat absorbed by fried foods can be significantly reduced by the application of edible coatings, a major contributory factor to the deterioration of meat quality is oxidation, a current challenge to the food industry [8]. Several chemical changes occur once oil is exposed to heat. These include oxidation and polymerization of fatty acids and degradation of triglyceride molecules into free fatty acids and glycerol. This can be exacerbated in the presence of air and water from food (which facilitates the hydrolysis) [9]. Thus, lipid oxidation could lead to shelf-life reduction and the formation of compounds in fried foods that are harmful to human health. Researchers [10] demonstrated that antioxidants can be used to improve the shelf-life of meat products. However, the use of synthetic antioxidants for meat preservation raised consumer concerns due to their toxicological effects and adverse effects on human health [11,12]. In light of these reasons, the need for naturally sourced antioxidants is being prioritized to replace synthetic antioxidants. 
Quercetin (3,3', $4^{\prime}, 5,7$-pentahydroxyflavone) is a flavonol-type flavonoid ubiquitously present in several fruits and vegetables, such as onions, propolis, cherries, broccoli, and even teas and wines [13-16]. A significant health benefit of quercetin is its ability to scavenge highly reactive species, such as peroxynitrite and hydroxyl radicals [17]. As an antioxidant, quercetin prevents oxidation by either hindering the formation of reactive oxygen species (ROS) or scavenging species responsible for oxidation initiation $\left(\mathrm{O}_{2} \bullet{ }^{-},{ }^{1} \mathrm{O}_{2}\right.$, etc.) or intercept radical oxidation propagators (LOO•). However, it should be kept in mind that antioxidants act via mixed mechanisms combining different types of antioxidation [18] Quercetin-3-O-glucoside (Q3G) esters are effective in inhibiting primary oxidation by 50\% to $100 \%$ in oil-in-water emulsion, and Q3G demonstrated more than $50 \%$ primary inhibition in bulk oil [19]. Quercetin is also used to treat hyperlipidemia and the prevention of obesity. In a recent study, obese human subjects were treated with quercetin supplements, and their results showed significant improvement in body composition of overweight and obese subjects [20].

According to a recent study, edible coatings can serve as a medium for incorporating antioxidant agents [21]. The incorporation of antioxidants into edible coatings is a developing technology to promote the development of functional foods, where bioactive compounds are embedded in the edible coating matrix. Bioactive edible coatings have the function of regulating the release rate of bioactive compounds into the desired product, eventually improving the shelf stability of the food product, and consequently impacting the consumer's health $[22,23]$.

Dark muscles (e.g., chicken drumsticks) contain higher heme protein and inorganic iron content than light muscles (e.g., chicken breast), which are the catalysts for lipid and protein oxidation. Thus, in this research, chicken drumsticks were used to study the oxidation behavior of the dark muscle due to exposure to heat (deep-frying) and quercetinin-edible coating as an antioxidant compound. The main objective of the present work was to evaluate the potential of a chicken protein-based coating formulated with quercetin in improving the oxidative stability of deep-fat-fried chicken drumsticks.

\section{Materials and Methods}

\subsection{Chicken Sample Preparation}

Chicken drumsticks bought from a local grocery shop were used for the study. Samples were cut using a manually operated cutting device into equal pieces, weighing approximately $10 \pm 1 \mathrm{~g}$. Subsequently, the samples were kept in a refrigerator at $4{ }^{\circ} \mathrm{C}$ for $24 \mathrm{~h}$.

\subsection{Protein Isolation from Chicken By-Product}

\subsubsection{Recovery and Brine Washing of Chicken By-Product}

Chicken byproducts, such as skins and meat left on the bone from the chicken drumstick, were minced through a $0.5 \mathrm{~cm}$ meat grinder (LEM grinder, 5 Big Bite Grinder- $0.35 \mathrm{HP}$, West Chester, OH, USA). The ground product was washed based on the process described by [24] to reduce the fat content of the protein used for isolation. However, slight modifications were made to the procedure. Next, 1 part of ground chicken was homogenized with 5 parts $\mathrm{NaCl}$ with $0.05 \mathrm{M}$ cold $\mathrm{NaCl}\left(2-4^{\circ} \mathrm{C}\right)$ for $2 \mathrm{~min}$ at $13,000 \mathrm{rpm}$ using a laboratory homogenizer (Homogenizer, OMNI International, Kennesaw, GA, USA). The homogenized sample was centrifuged at a speed of $5000 \times g$ using a centrifuge (Thermo Scientific, Model ST 16 Centrifuge Series, Asheville, NC, USA) set at $4{ }^{\circ} \mathrm{C}$. The chicken slurry obtained after centrifugation was used for protein isolation.

\subsubsection{Isoelectric Solubilization/Precipitation and Quantification of Protein Content}

Protein recovery from chicken byproducts was performed according to [25]. The collected chicken slurry was homogenized with cold deionized water (1 part of washed chicken slurry to 6 parts of deionized water) for $5 \mathrm{~min}$ at a speed of 13,000 rpm at a controlled temperature of $4{ }^{\circ} \mathrm{C}$. About $6 \mathrm{~L}$ of the homogenate was measured into a beaker, and its $\mathrm{pH}$ was adjusted to $11.50 \pm 0.05$ with a $10 \mathrm{~N} \mathrm{NaOH}$ solution. The solution was 
held at this $\mathrm{pH}$ for $10 \mathrm{~min}$ and centrifuged for $20 \mathrm{~min}$ at $5000 \times \mathrm{g}$ and $4{ }^{\circ} \mathrm{C}$. Following centrifugation, the solution was separated into three layers. The $\mathrm{pH}$ of the middle layer containing the chicken protein was adjusted to $5.5 \pm 0.05$ to precipitate with $6 \mathrm{~N} \mathrm{HCl}$. The solution was left to react for another $10 \mathrm{~min}$ and centrifuged for $20 \mathrm{~min}$ at $5000 \times g$ and $4{ }^{\circ} \mathrm{C}$. Two layers were formed after centrifugation. The top layer containing water was discarded and the bottom layer containing the protein, hereafter called chicken protein isolate (CPI), was collected.

The protein content of the CPI was measured using the Bradford method with slight modifications [26]. Bovine serum albumin was dissolved in a solution containing $0.1 \mathrm{M}$ $\mathrm{NaOH}$ and $3.5 \% \mathrm{NaCl}$ to prepare standard solutions. Subsequently, $5 \mathrm{~g}$ of CPI was measured and homogenized with $30 \mathrm{~mL}$ of $0.1 \mathrm{M}$ and $3.5 \% \mathrm{NaCl}$ using a laboratory homogenizer. The homogenate obtained was centrifuged at $4000 \times g$ at $4{ }^{\circ} \mathrm{C}$ for $30 \mathrm{~min}$. The supernatant was collected for protein analysis. Standard and sample solutions, measuring $20 \mu \mathrm{L}$ were plated into wells of microplates. Accurately measured $200 \mu \mathrm{L}$ of Bradford reagent was added into wells that were filled with either standard or sample solutions. The plates were incubated for $20 \mathrm{~min}$ at $37^{\circ} \mathrm{C}$. Afterward, samples were placed in a spectrophotometer and read at an absorbance of $595 \mathrm{~nm}$.

\subsection{DPPH Free-Radical Scavenging Activity of Quercetin}

Quercetin dihydrate (>95\% purity) was obtained from Selleckchem (Houston, TX, USA). The free-radical scavenging ability of quercetin against DPPH radicals was assessed as described by [27]. Briefly, $100 \mu \mathrm{L}$ of $0.125,0.25,0.5,1$, and $2 \mathrm{mg} / \mathrm{mL}$ quercetin was prepared with $70 \mu \mathrm{M}$ DPPH. Positive and negative control samples of $100 \mu \mathrm{L}$ butylated hydroxytoluene (BHT) at $10 \mathrm{mM}$ and $100 \mu \mathrm{L}$ methanol were used, respectively. The samples were incubated for $30 \mathrm{~min}$ in the dark at room temperature. Subsequently, the absorbance was measured at $517 \mathrm{~nm}$ using a spectrophotometer. The DPPH radical scavenging activity of the tested samples was determined using the following formula:

$$
\% \text { scavenging activity }=\frac{\text { absorbance of quercetin or BHT }}{\text { absorbance of negative control }} \times 100
$$

Further, $\mathrm{EC}_{50}$ and $\mathrm{T}_{\mathrm{EC} 50}$ were calculated.

\subsection{Preparation of Bioactive Edible Coating}

Our previous study showed that $10 \%$ protein in edible coating resulted in the highest fat uptake reduction in deep-fat-fried chicken drumsticks [7]. Also, $\mathrm{EC}_{50}$ was calculated to determine the concentration at which quercetin reduced the DPPH radical by $50 \%$ [28]. Thus, edible coatings in this study were prepared by slowly dissolving the CPI in a $1 \mathrm{mg} / \mathrm{mL}$ quercetin-in-ethanol solution to form a 10\% protein-based edible coating. For control, CPI was formulated with only ethanol to form a $10 \%$ edible coating. Glycerol was added at $0.4 \%(w / w)$ of the CPI, and the resulting solution was stirred for approximately $15 \mathrm{~min}$. The $\mathrm{pH}$ of the edible coating was adjusted to $11 \pm 0.05$ with a $10 \mathrm{~N}$ $\mathrm{NaOH}$ solution. Subsequently, the edible coating was stirred uniformly with a laboratory homogenizer at 13,000 rpm for $1 \mathrm{~min}$. Afterward, the $\mathrm{pH}$ was readjusted to $7 \pm 0.05 \mathrm{using}$ $6 \mathrm{~N} \mathrm{HCl}$ solution.

\subsection{Sample Preparation for Frying}

Chicken pieces were rinsed under running water, predusted, and dipped in the edible coating. The coated samples were shaken to remove excess coating. Subsequently, the samples were fully immersed in the batter for $15 \mathrm{~s}$. A commercial batter (Louisiana Chicken Batter Mix, Baton Rouge, LA, USA) was prepared according to the manufacturer's instructions. Finally, samples were evenly rolled in breadcrumbs. 


\subsection{Deep-Frying}

Coated chicken drumsticks were deep-fried at $177.7^{\circ} \mathrm{C}$ in a bench-top deep fryer (Presto ${ }^{\circledR}$ Dual ProFryTM/1800W, National Presto Industries Inc., Appleton, WI, USA) for 4 min. Particles of fried food building up in the oil during repeated frying operations dramatically lower the quality of frying oil. To avoid this, new and fresh canola oil was used for each batch of treatment. A data logging thermometer was connected to the fryer to monitor and control the frying temperature. The core temperature was checked to reach $73^{\circ} \mathrm{C}$ [29]. The fried samples were removed from the oil using prongs and allowed to cool.

\subsection{Storage Condition}

Fried chicken samples were vacuum packed in polyethylene bags, labeled, and stored for 10 days at $4 \pm 1{ }^{\circ} \mathrm{C}$. The samples were randomly taken during the refrigerated storage and tested for the following analyses on days $0,2,4,6,8$, and 10 .

\subsection{TBARS Value}

Using the 2-thiobarbituric acid reactive substances (TBARS) assay of malondialdehyde (MDA), the oxidative stability of deep-fat-fried chicken samples was determined according to the previously reported method of [30]. TBARS values were determined by using a molar absorptivity of MDA $\left(156,000 \mathrm{M}^{-1} \mathrm{~cm}^{-1}\right)$, and results were reported as $\mathrm{mg}$ $\mathrm{MDA} / \mathrm{kg}$ sample.

\subsection{Color Properties}

A portable Minolta Chroma CR-400 colorimeter (Minolta Camera Co. Ltd., Osaka, Japan) was used to evaluate the color profile of chicken drumsticks. The Commission Internationale d'Eclairage of France method was employed to determine the $L^{*} a^{*} b^{*}$ tristimulus color values.

\subsection{Determination of $p H$}

The deep-fried chicken samples (5 g) were homogenized for $1 \mathrm{~min}$ with distilled water $(20 \mathrm{~mL})$. The $\mathrm{pH}$ value was determined using a calibrated digital $\mathrm{pH}$ meter (OMNI International, Kennesaw, GA, USA) [31].

\subsection{Textural Analysis}

Textural properties of samples were assessed using a texture analyzer (Model TA-XT2, Texture Analyzer, Texture Technologies Corp., Scarsdale, NY, USA). A puncture test was done at $5 \mathrm{~mm} / \mathrm{s}$ using a $1 / 8$ spindle with $15 \%$ penetrating thickness of the crust.

\subsection{Statistical Analysis}

For each parameter, a duplicate sample plus three trials were used. Six observations were carried out for consistency of the results. The mean values were expressed as results \pm standard deviation. A two-way analysis of variance (ANOVA) was used to determine the effects at a significant level of $p<0.05$ using SAS system software (SAS, version 16.0, SAS 49 Institute, Cary, NC, USA). The differences in the mean values between treatments were calculated using Tukey's test.

\section{Results and Discussion}

\subsection{Antioxidant Value of Quercetin}

To test the capacity of quercetin to neutralize free radicals, DPPH• (1, 1-diphenyl-2 picrylhydrazyl) scavenging activity assay was conducted. The DPPH radical scavenging activity levels of quercetin at the concentrations of $0.125,0.25,0.5,1$, and $2 \mathrm{mg} / \mathrm{mL}$ were 9.15 , 23.5, 57.57, 90.27, and 94.06\%, respectively. As seen in Figure 1, increasing concentration of quercetin reflected a corresponding significantly $(p<0.05)$ higher percentage of inhibition and the DPPH• was reduced to its nonradical form by quercetin. This test showed that quercetin at $1 \mathrm{mg} / \mathrm{mL}$ had the highest scavenging activity. This was further confirmed 
with $\mathrm{EC}_{50}$ and $\mathrm{T}_{\mathrm{EC} 50}$ values of $0.4 \mathrm{mg} / \mathrm{mL}$ and $4.5 \mathrm{~min}$, respectively. Good antioxidant activity is defined by a low concentration and short time. The research in [32] classified different antioxidant compounds according to $\mathrm{T}_{\mathrm{EC} 50}$ values. Ascorbic acid, alpha-tocopherol, and rutin are classified as rapid, intermediate, and slow in terms of kinetic behavior with $\mathrm{T}_{\mathrm{EC} 50}$ values of $5,5-30$, and $>30 \mathrm{~min}$, respectively. Therefore, quercetin could be considered to have rapid antioxidant activity.

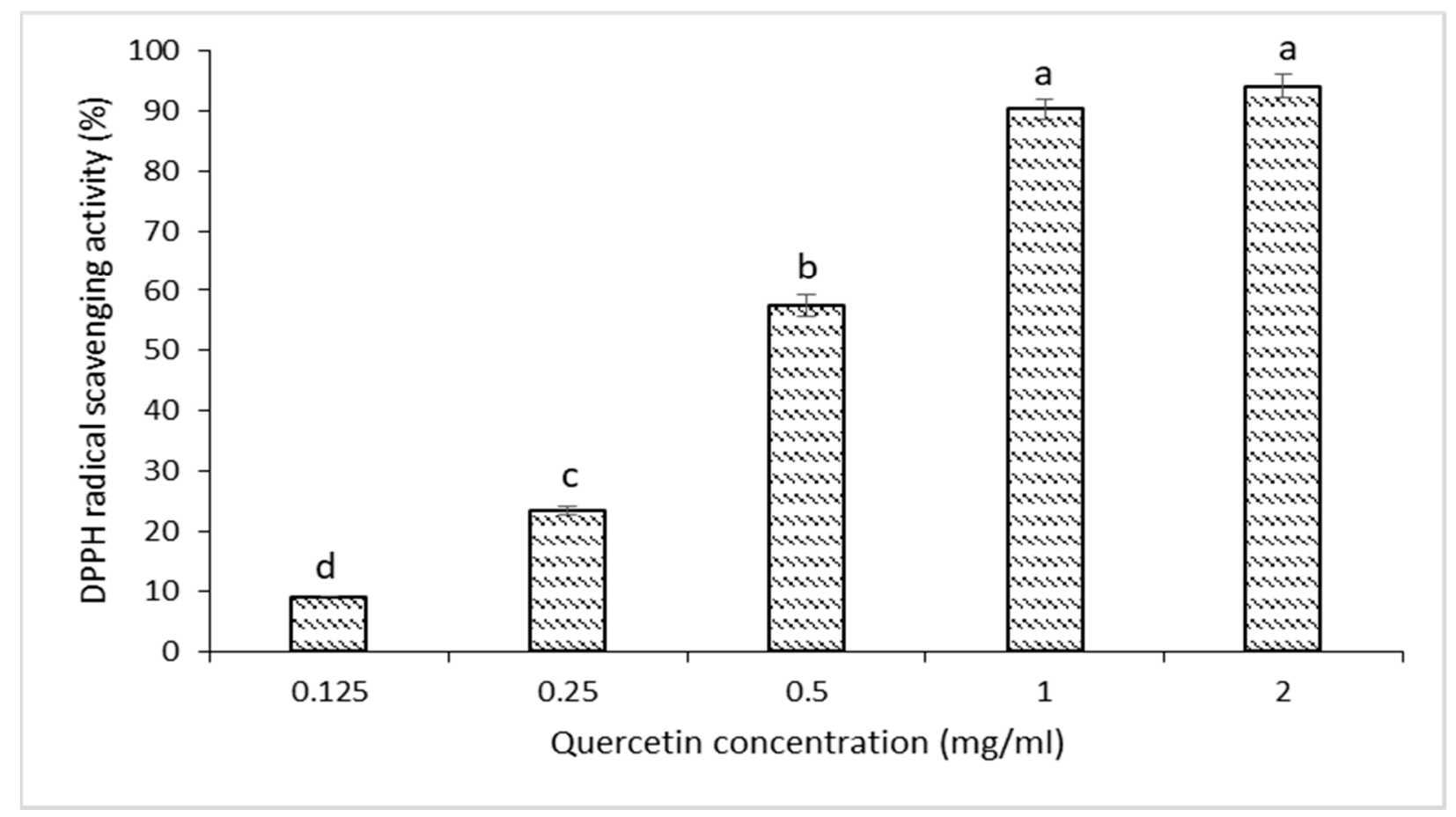

Figure 1. DPPH radical scavenging activity (\%) of quercetin. Data are given as means values \pm SD. Different letters on the top of data bars indicate significant differences (Tukey's test, $p<0.05$ ) between mean values.

\subsection{Oxidative Stability of Deep-Fat Fried Chicken}

TBARS was determined to evaluate the efficacy of quercetin in inhibiting undesired changes in fats occurring during the storage of deep-fat-fried chicken samples. The results recorded for malondialdehyde (MDA) contents in control and treated deep-fat-fried chicken samples are shown in Figure 2. The initial TBARS value increased continuously with increasing storage days for control and treated samples from $1.13 \mathrm{mg} \mathrm{MDA} / \mathrm{kg}$ and $1.15 \mathrm{mg}$ MDA $/ \mathrm{kg}$ to $7.14 \mathrm{mg} \mathrm{MDA} / \mathrm{kg}$ and $5.58 \mathrm{mg} \mathrm{MDA} / \mathrm{kg}$, respectively. Although the treated samples showed lower numerical values for TBARS, they did not significantly differ from the control samples. A similar ascending trend was found by [33], who measured the TBARS values of emulsion sausage of pork with onion peel extract at $0.05 \%$, since onion peel extract contains quercetin. There was no significant difference between the TBARS values of the control samples, and the samples treated with onion peel extract. However, in contrast to our results, [34] found that when onion peel extract $(0.5 \%)$ was added to the irradiated pork Jerky, lower peroxide values were recorded. They referred to this effect as the quercetin radical scavenging activity.

A study by [35] showed that when quercetin was mixed with minced fish, the $\mathrm{EC}_{50}$ significantly increased and the quercetin lost its efficiency. They assumed this loss of efficiency was due to the interaction between the quercetin molecule and the muscle constituents. However, salt addition did not impact the antioxidant activity of the quercetin.

Furthermore, [36] indicated that boiling would result in an $18 \%$ decrease in quercetin concentration compared to raw onion. They noticed a $14.8 \%$ and $20.1 \%$ decrease in the 
diglucoside and monoglucoside contents of the boiled onions, respectively, showing the possibility of quercetin leaching into cook water due to low stability.

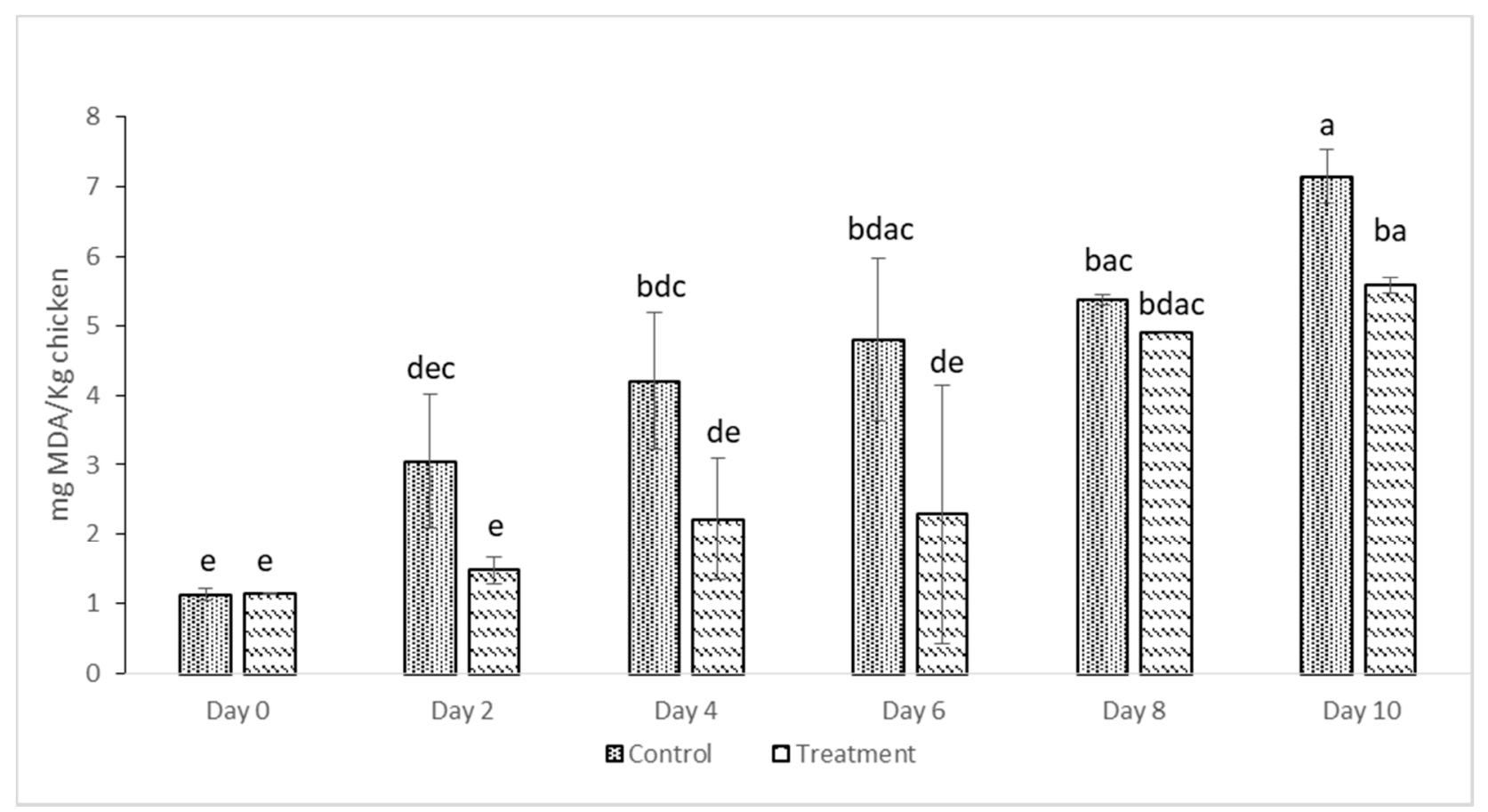

Figure 2. Thiobarbituric acid reactive substances (TBARS) values of control and treated deep-fat-fried chicken drumsticks for 10 days. Data are given as means values \pm SD. Different letters on the top of data bars indicate significant differences (Tukey's test, $p<0.05$ ) between mean values.

Others $[37,38]$ showed that five minutes of frying onions in sunflower oil, butter, and rapeseed oil led to $21 \%, 24 \%$, and $39 \%$ quercetin losses. In addition, mechanical peeling of onions during sample preparation in addition to the high temperature of frying could contribute to this quercetin loss [38].

The duration of cooking also appeared to impact on the quercetin loss. Several studies reported that cooking times between 3 and 60 min resulted in 20.6-75\% quercetin loss [37-41]. In general, longer cooking time results in greater cooking loss. This loss due to boiling or frying may be due to leaching of the quercetin in the cooking medium rather than chemical degradation of the quercetin. In the case of our study, there might be some leaching of the quercetin while preparing the edible coating. Homogenization may have also contributed as a mechanical factor in further loss of the quercetin in the final product.

Phenolic compounds are capable of limiting oxidation by two major pathways [8]. First, by terminating the oxidation cycle at the propagation phase by giving up electrons to inhibit the formation of lipid and protein radicals, and the second pathway involves eliminating free radicals or reactive oxygen species (ROS) initiators to avoid the actions of chain-initiating radicals. Also, lipid oxidation can be inhibited by stabilizing radical initiators into inactive and insoluble forms. This is achieved by binding metals such as iron and copper as metal chelators. Since quercetin is mainly a phenol-based compound, determination of the radical scavenging activity should be an adequate method to evaluate the antioxidant ability of the quercetin. However, the possibility of lipid and protein interactions with quercetin when blended with the meat is unavoidable, which consequently results in a partial loss in scavenging activity. Further, high temperature during frying and leaching of the quercetin in the edible coating and oil could represent other contributing factors leading to quercetin losses and, consequently, ineffectiveness in lipid oxidation retardation. 


\subsection{Instrumental Color}

Data for measured color parameters of deep-fat-fried chicken are shown in Table 1. CIE $L^{*}$ (lightness) values of both control and treated samples decreased gradually toward the end of storage time $(p<0.05)$. Although $b^{*}$ (yellowness) values of the control samples increased when compared with the first day of storage, it remained stable toward the end of storage. The samples treated with quercetin showed fluctuation trends in $b^{*}$ values. A similar result was found for chicken nuggets prepared with leg meat [42]. They related the darker color of the meat to the high-fat content of drumsticks, which resulted in oxidation during storage time and, consequently, higher $L^{*}$ and $b^{*}$ values. Similarly, [43] noticed the same trend of color change for the chicken nuggets during storage time. They justified the color changes in chicken nuggets by myoglobin conversion to metmyoglobin during storage time. Discoloration of meat in response to lipid oxidation is attributed to the formation of aldehydes, alkanes, and conjugated dienes, which are products of the interaction of alkyl and peroxy radicals, which may further cause protein oxidation [8]. However, no significant changes were noticed for $a^{*}$ (redness) values in control and treated samples $(p$ $>0.05$ ). A study by [44] found that essential oil addition at high concentrations could result in a reduction of redness due to the prooxidant effect. However, these findings contradict our results, in which no significant changes were observed in $a^{*}$ values.

Table 1. Changes in color of deep-fat-fried chicken drumsticks.

\begin{tabular}{ccccccc}
\hline $\begin{array}{c}\text { Days of } \\
\text { Storage }\end{array}$ & \multicolumn{2}{c}{$\boldsymbol{L}^{*}$} & & $\boldsymbol{a}^{*}$ & & $\boldsymbol{b}^{*}$ \\
\hline & Control & Treatment & Control & Treatment & Control & Treatment \\
\hline 0 & $52.89 \pm 3.89^{\mathrm{a}}$ & $52.23 \pm 0.53^{\mathrm{ab}}$ & $7.51 \pm 0.91^{\mathrm{a}}$ & $8.88 \pm 0.52^{\mathrm{a}}$ & $3.05 \pm 0.71^{\mathrm{c}}$ & $6.86 \pm 3.65^{\mathrm{bc}}$ \\
2 & $48.71 \pm 0.92^{\mathrm{abcd}}$ & $50.54 \pm 0.97^{\mathrm{abc}}$ & $8.10 \pm 0.48^{\mathrm{a}}$ & $8.69 \pm 1.45^{\mathrm{a}}$ & $9.25 \pm 1.08^{\mathrm{ab}}$ & $9.64 \pm 0.99^{\mathrm{ab}}$ \\
4 & $47.92 \pm 1.57^{\mathrm{abcd}}$ & $49.36 \pm 0.82^{\mathrm{abc}}$ & $8.03 \pm 1.26^{\mathrm{a}}$ & $9.33 \pm 0.91^{\mathrm{a}}$ & $12.17 \pm 3.24^{\mathrm{ab}}$ & $14.31^{\mathrm{ab}} \pm 2.39^{\mathrm{a}}$ \\
6 & $48.51 \pm 1.55^{\mathrm{abcd}}$ & $48.40 \pm 2.22^{\mathrm{abcd}}$ & $7.89 \pm 0.07^{\mathrm{a}}$ & $8.56 \pm 2.15^{\mathrm{a}}$ & $12.51 \pm 0.33^{\mathrm{ab}}$ & $12.64 \pm 3.17^{\mathrm{ab}}$ \\
8 & $46.19 \pm 1.15^{\mathrm{cd}}$ & $47.33 \pm 2.25^{\mathrm{bcd}}$ & $7.38 \pm 0.50^{\mathrm{a}}$ & $7.78 \pm 1.24^{\mathrm{a}}$ & $11.17 \pm 1.70^{\mathrm{ab}}$ & $13.52 \pm 0.90^{\mathrm{a}}$ \\
10 & $45.75 \pm 0.98^{\mathrm{cd}}$ & $43.91 \pm 1.62^{\mathrm{d}}$ & $7.17 \pm 0.56^{\mathrm{a}}$ & $7.36 \pm 1.40^{\mathrm{a}}$ & $12.24 \pm 1.64^{\mathrm{ab}}$ & $11.47 \pm 2.13^{\mathrm{ab}}$ \\
\hline
\end{tabular}

Data are given as mean values \pm standard deviation. Different letters within the same column indicate significant differences (Tukey's test, $p<0.05)$ between mean values.

\subsection{Texture Properties}

The puncture test mimics the function of the tooth in chewing the food, particularly for crispy, puffed food products. This provides data related to the mechanical properties of the crusts in fried food products which correlates with sensory criteria, i.e., crispiness [45]. Puncture force measured from day 0 up to day 4 of storage revealed no variation between control and treated samples $(p>0.05)$. Puncture force measured on treated samples, however, revealed an increase from day 2 to day 4 and from day 4 to day $6(p<0.05)$. Likewise, the force required to penetrate the crust of control samples increased $(p>0.05)$ from day 0 to day 6 . As observed in Figure 3, both control and treated samples increased in puncture force during the 10-day storage; nonetheless, it was found that treated samples demonstrated a slightly higher puncture force compared to control samples. These results were consistent with those obtained by [46] who analyzed the textural properties of porcine liver pâté by using penetration tests during refrigerated storage. They noticed significantly higher puncture force values when BHT was added to the liver pâté. Likewise, [47] they also found greater hardness for lamb meat when it was fed on quercetin. The observed increase in puncture results is attributed to the polymerization of lipids and proteins [46]. The lower puncture results in control samples could be due to proteolytic changes that take place in myofibrillar proteins. 


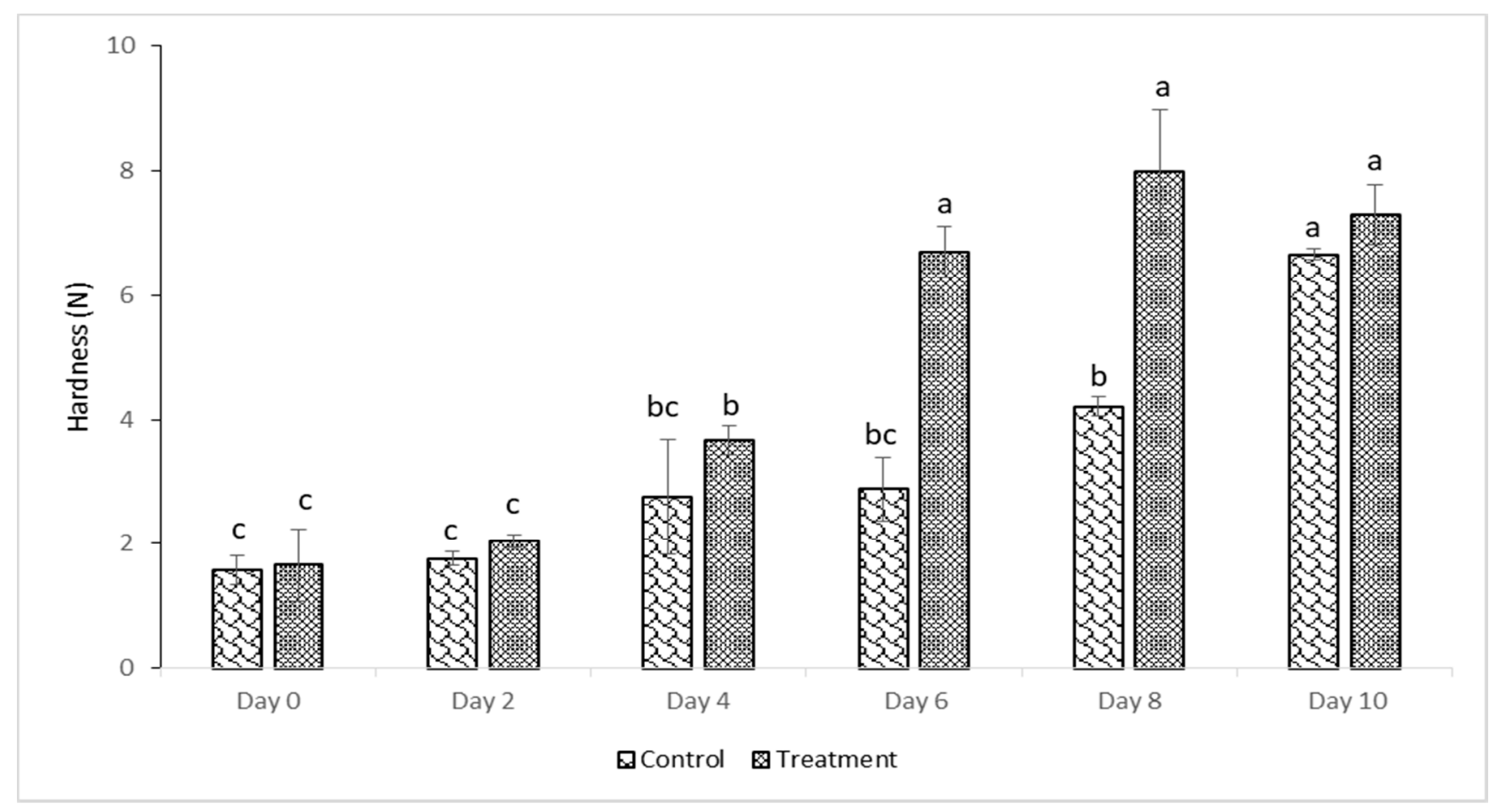

Figure 3. Maximum peak puncture forces of deep-fat fried samples. Data are given as mean values \pm standard deviation. Different letters on the top of data bars indicate significant differences (Tukey's Test, $p<0.05$ ) between mean values.

\section{5. $\mathrm{pH}$ Value}

Figure 4 shows the effect of quercetin on the $\mathrm{pH}$ of deep-fat-fried chicken samples during refrigerated storage at $4{ }^{\circ} \mathrm{C}$ for 10 days. The initial $\mathrm{pH}$ levels of the control and treatment samples were $6.63 \pm 0.02$ and $6.58 \pm 0.06$, respectively. The $\mathrm{pH}$ of control samples decreased significantly on day 4 to $6.51(p<0.05)$. On the other hand, the $\mathrm{pH}$ of treated samples only revealed a statistically significant variation on day $6(6.44 \pm 0.07)(p<0.05)$. Both control and treatment samples further decreased to $6.32 \pm 0.01$ and $6.32 \pm 0.02$, respectively $(p<0.05)$. These results were consistent with findings from [48]. The authors showed that deep-fried chicken nuggets treated with ganghwayakssuk ethanolic extract and control decreased in $\mathrm{pH}$ until seven days. A vital indicator of food stability associated with microbial and chemical reactions that culminate in food spoilage is the $\mathrm{pH}$ [48]. FernándezLópez and Sayas-Barberá [49] revealed that the growth of lactic acid bacteria, which results in lactic acid build-up, among other factors, could be attributed to a decrease in the $\mathrm{pH}$ of meat products. 


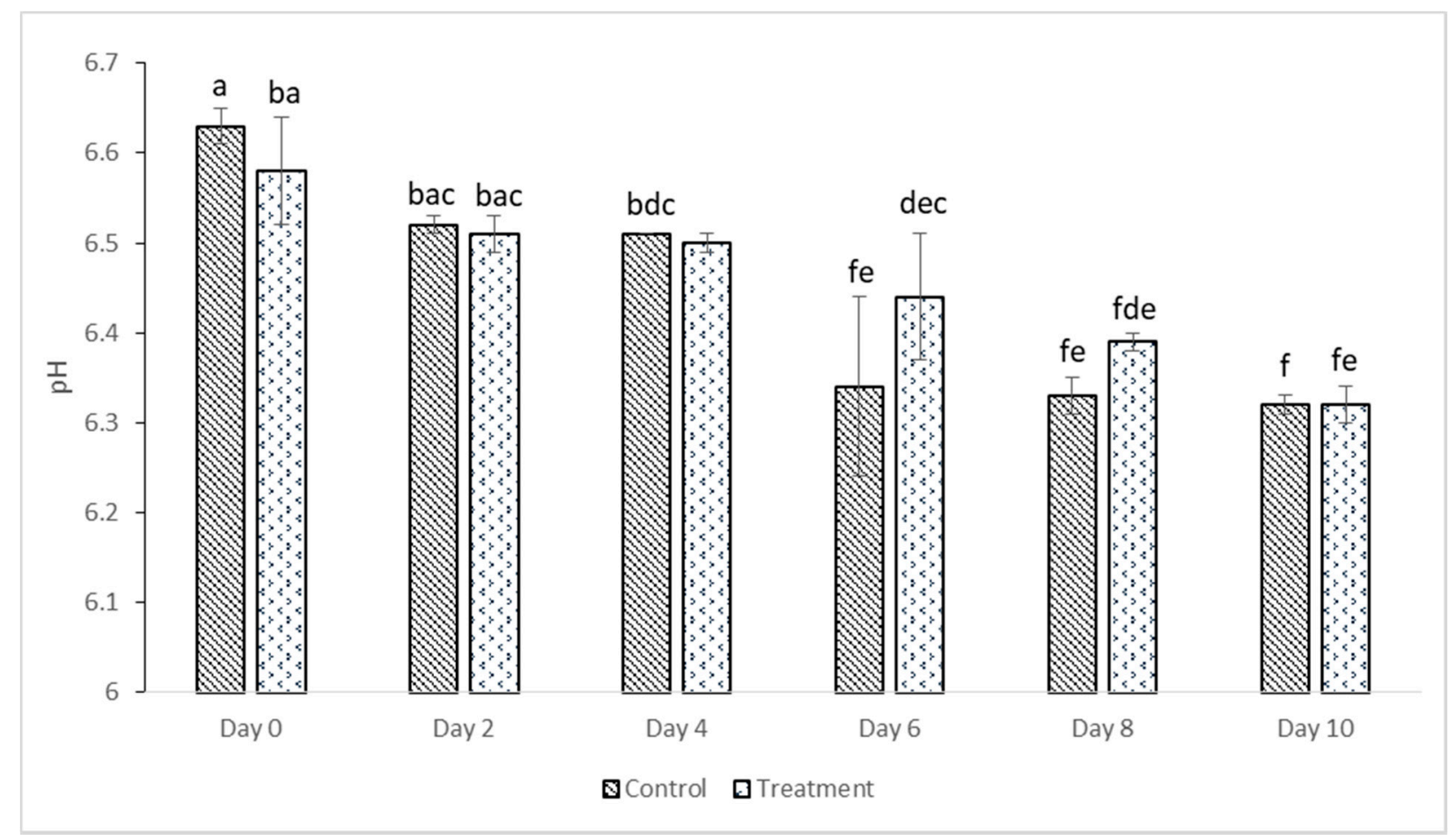

Figure 4. $\mathrm{pH}$ values of control and treated deep-fat-fried chicken samples. Data are given as mean values \pm standard deviation. Different letters on the top of data bars indicate significant differences (Tukey's test, $p<0.05$ ) between mean values.

\section{Conclusions}

In the present study, quercetin at $1 \%$ was incorporated in the edible coating to enhance the oxidative stability and other physicochemical properties of deep-fat-fried chicken drumsticks during 10 days of storage. However, no significant difference in TBARS values was found between the control and treated samples. Puncture test and CIE $L^{*}$ and $b^{*}$ showed an increase when quercetin was incorporated in the edible coating. Also, the $\mathrm{pH}$ values of both control and treated samples decreased by the end of storage time. Therefore, higher concentrations of quercetin may be needed for effective inhibition of lipid oxidation.

Author Contributions: Conceptualization, R.T.; methodology, D.A.-O.; software, K.A.; validation, R.T., D.A.-O., and K.A.; formal analysis, K.A.; investigation, R.T.; resources, R.T.; data curation, D.A.-O.; writing—original draft preparation, K.A.; writing—review and editing, K.A. and R.T.; visualization, K.A.; supervision, R.T.; project administration, R.T.; funding acquisition, R.T. All authors have read and agreed to the published version of the manuscript.

Funding: This work was funded through the National Institute for Food and Agriculture of the United States Department of Agriculture, Project No. NC.X-311-5-18-170-1, in the Agricultural Research Program at North Carolina Agricultural and Technical State University.

Institutional Review Board Statement: Not applicable.

Informed Consent Statement: Not applicable.

Data Availability Statement: Data are contained within this article.

Conflicts of Interest: The authors declare no conflict of interest.

\section{References}

1. Donfrancesco, C.; Noce, C.L.; Brignoli, O.; Riccardi, G.; Ciccarelli, P.; Dima, F.; Palmieri, L.; Giampaoli, S. Italian network for obesity and cardiovascular disease surveillance: A pilot project. BMC Fam. Pract. 2008, 9, 53. [CrossRef]

2. Pedreschi, F.; Moyano, P. Oil uptake and texture development in fried potato slices. J. Food Eng. 2005, 70, 557-563. [CrossRef] 
3. Soriguer, F.; Rojo-Martínez, G.; Dobarganes, M.C.; Almeida, J.M.G.; Esteva, I.; Beltrán, M.; De Adana, M.S.R.; Tinahones, F.; Gómez-Zumaquero, J.M.; García-Fuentes, E.; et al. Hypertension is related to the degradation of dietary frying oils. Am. J. Clin. Nutr. 2003, 78, 1092-1097. [CrossRef]

4. Mozaffarian, D.; Benjamin, E.J.; Go, A.S.; Arnett, D.K.; Blaha, M.J.; Cushman, M.; de Ferranti, S.; Després, J.; Fullerton, H.J.; Howard, V.J.; et al. Heart disease and stroke statistics-2015 update: A report from the American Heart Association. Circulation 2015, 131, e29-e322. [CrossRef] [PubMed]

5. Williams, R.; Mittal, G.; Williams, R.; Mittal, G. Water and Fat Transfer Properties of Polysaccharide Films on Fried Pastry Mix. LWT 1999, 32, 440-445. [CrossRef]

6. Azahrani, M.H.; Ananey-Obiri, D.; Matthews, L.; Tahergorabi, R. Development of low-fat fried fish using a two-prong strategy. CyTA J. Food 2019, 17, 882-891. [CrossRef]

7. Ananey-Obiri, D.; Matthews, L.; Tahergorabi, R. Chicken processing by-product: A source of protein for fat uptake reduction in deep-fried chicken. Food Hydrocoll. 2020, 101, 105500. [CrossRef]

8. Falowo, A.B.; Fayemi, P.O.; Muchenje, V. Natural antioxidants against lipid-protein oxidative deterioration in meat and meat products: A review. Food Res. Int. 2014, 64, 171-181. [CrossRef]

9. Choe, E.; Min, D.B. Chemistry of Deep-Fat Frying Oils. J. Food Sci. 2007, 72, R77-R86. [CrossRef]

10. Ahmad Mir, S.; Ahmad Masoodi, F.; Raja, J. Influence of natural antioxidants on microbial load, lipid oxidation and sensorial quality of rista-A traditional meat product of India. Food Biosci. 2017, 20, 79-87. [CrossRef]

11. Juntachote, T.; Berghofer, E.; Siebenhandl, S.; Bauer, F. The antioxidative properties of Holy basil and Galangal in cooked ground pork. Meat Sci. 2006, 72, 446-456. [CrossRef] [PubMed]

12. Karre, L.; Lopez, K.; Getty, K.J. Natural antioxidants in meat and poultry products. Meat Sci. 2013, 94, 220-227. [CrossRef]

13. Erlund, I. Review of the flavonoids quercetin, hesperetin, and naringenin. Dietary sources, bioactivities, bioavailability, and epidemiology. Nutr. Res. 2004, 24, 851-874. [CrossRef]

14. Terao, J. Factors modulating bioavailability of quercetin-related flavonoids and the consequences of their vascular function. Biochem. Pharmacol. 2017, 139, 15-23. [CrossRef] [PubMed]

15. Pobiega, K.; Przybył, J.L.; Żubernik, J.; Gniewosz, M. Prolonging the Shelf Life of Cherry Tomatoes by Pullulan Coating with Ethanol Extract of Propolis During Refrigerated Storage. Food Bioprocess Technol. 2020, 13, 1447-1461. [CrossRef]

16. Pobiega, K.; Kraśniewska, K.; Przybył, J.L.; Bączek, K.; Żubernik, J.; Witrowa-Rajchert, D.; Gniewosz, M. Growth Biocontrol of Foodborne Pathogens and Spoilage Microorganisms of Food by Polish Propolis Extracts. Molecules 2019, 24, 2965. [CrossRef] [PubMed]

17. Zhang, M.; Xu, L.; Zhang, L.; Guo, Y.; Qi, X.; He, L. Effects of quercetin on postharvest blue mold control in kiwifruit. Sci. Hortic. 2018, 228, 18-25. [CrossRef]

18. Laguerre, M.; Lecomte, J.; Villeneuve, P. Evaluation of the ability of antioxidants to counteract lipid oxidation: Existing methods, new trends and challenges. Prog. Lipid Res. 2007, 46, 244-282. [CrossRef] [PubMed]

19. Warnakulasuriya, S.N.; Ziaullah; Rupasinghe, H.P.V. Long Chain Fatty Acid Acylated Derivatives of Quercetin-3-O-Glucoside as Antioxidants to Prevent Lipid Oxidation. Biomolecules 2014, 4, 980-993. [CrossRef] [PubMed]

20. Lee, J.-S.; Cha, Y.-J.; Lee, K.-H.; Yim, J.-E. Onion peel extract reduces the percentage of body fat in overweight and obese subjects: A 12-week, randomized, double-blind, placebo-controlled study. Nutr. Res. Pract. 2016, 10, 175-181. [CrossRef]

21. Ananey-Obiri, D.; Matthews, L.; Azahrani, M.H.; Ibrahim, S.A.; Galanakis, C.M.; Tahergorabi, R. Application of protein-based edible coatings for fat uptake reduction in deep-fat fried foods with an emphasis on muscle food proteins. Trends Food Sci. Technol. 2018, 80, 167-174. [CrossRef]

22. Odila Pereira, J.; Soares, J.; Sousa, S.; Madureira, A.R.; Gomes, A.; Pintado, M. Edible films as carrier for lactic acid bacteria. LWT 2016, 73, 543-550. [CrossRef]

23. Pothakamury, U.R.; Barbosa-Cánovas, G.V. Fundamental aspects of controlled release in foods. Trends Food Sci. Technol. 1995, 6, 397-406. [CrossRef]

24. Tongnuanchan, P.; Benjakul, S.; Prodpran, T.; Songtipya, P. Characteristics of film based on protein isolate from red tilapia muscle with negligible yellow discoloration. Int. J. Biol. Macromol. 2011, 48, 758-767. [CrossRef] [PubMed]

25. Tahergorabi, R.; Beamer, S.K.; Matak, K.E.; Jaczynski, J. Effect of isoelectric solubilization/precipitation and titanium dioxide on whitening and texture of proteins recovered from dark chicken-meat processing by-products. LWT 2011, 44, 896-903. [CrossRef]

26. Bradford, M.M. A rapid and sensitive method for the quantitation of microgram quantities of protein utilizing the principle of protein-dye binding. Anal. Biochem. 1976, 72, 248-254. [CrossRef]

27. Yu, L.; Haley, S.; Perret, J.; Harris, M.; Wilson, J.; Qian, M. Free Radical Scavenging Properties of Wheat Extracts. J. Agric. Food Chem. 2002, 50, 1619-1624. [CrossRef] [PubMed]

28. Alexander, B.S.; Browse, D.J.; Reading, S.; Benjamin, I. A simple and accurate mathematical method for calculation of the EC50. J. Pharmacol. Toxicol. Methods 1999, 41, 55-58. [CrossRef]

29. Shaltout, F.; Marionette, Z.N.; Shakran, A. Quality of battered and breaded chicken meat products. Glob. J. Agric. Food Saf. Sci. 2014, 1, 283-299.

30. Witte, V.C.; Krause, G.F.; Bailey, M.E. A new extraction method for determining 2-thiobarbituric acid values of pork and beef during storage. J. Food Sci. 1970, 35, 582-585. [CrossRef] 
31. Alakhrash, F.; Anyanwu, U.; Tahergorabi, R. Physicochemical properties of Alaska pollock (Theragra chalcograma) surimi gels with oat bran. LWT 2016, 66, 41-47. [CrossRef]

32. Sánchez-Moreno, C.; Larrauri, J.A.; Saura-Calixto, F. A procedure to measure the antiradical efficiency of polyphenols. J. Sci. Food Agric. 1998, 76, 270-276. [CrossRef]

33. Lee, S.-Y.; Kim, H.-W.; Hwang, K.-E.; Song, D.-H.; Choi, M.-S.; Ham, Y.-K.; Choi, Y.-S.; Lee, J.-W.; Lee, S.-K.; Kim, C.-J. Combined Effect of Kimchi Powder and Onion Peel Extract on Quality Characteristics of Emulsion Sausages Prepared with Irradiated Pork. Food Sci. Anim. Resour. 2015, 35, 277-285. [CrossRef] [PubMed]

34. Kim, H.-J.; Jung, S.; Yong, H.I.; Bae, Y.S.; Kang, S.N.; Kim, I.S.; Jo, C. Improvement of microbiological safety and sensorial quality of pork jerky by electron beam irradiation and by addition of onion peel extract and barbecue flavor. Radiat. Phys. Chem. 2014, 98, 22-28. [CrossRef]

35. Montero, P.; Giménez, B.; Perez-Mateos, M.; Gómez-Guillén, M.C. Oxidation stability of muscle with quercetin and rosemary during thermal and high-pressure gelation. Food Chem. 2005, 93, 17-23. [CrossRef]

36. Lombard, K.; Peffley, E.; Geoffriau, E.; Thompson, L.; Herring, A. Quercetin in onion (Allium cepa L.) after heat-treatment simulating home preparation. J. Food Compos. Anal. 2005, 18, 571-581. [CrossRef]

37. Crozier, A.; Lean, M.E.J.; McDonald, M.S.; Black, C. Quantitative Analysis of the Flavonoid Content of Commercial Tomatoes, Onions, Lettuce, and Celery. J. Agric. Food Chem. 1997, 45, 590-595. [CrossRef]

38. Ewald, C.; Fjelkner-Modig, S.; Johansson, K.; Sjöholm, I.; Åkesson, B. Effect of processing on major flavonoids in processed onions, green beans, and peas. Food Chem. 1999, 64, 231-235. [CrossRef]

39. Hirota, S.; Shimoda, T.; Takahama, U. Tissue and Spatial Distribution of Flavonol and Peroxidase in Onion Bulbs and Stability of Flavonol Glucosides during Boiling of the Scales. J. Agric. Food Chem. 1998, 46, 3497-3502. [CrossRef]

40. Makris, D.P.; Rossiter, J.T. Domestic Processing of Onion Bulbs (Allium cepa) and Asparagus Spears (Asparagus officinalis): Effect on Flavonol Content and Antioxidant Status. J. Agric. Food Chem. 2001, 49, 3216-3222. [CrossRef]

41. Price, K.R.; Bacon, J.R.; Rhodes, M.J. Effect of storage and domestic processing on the content and composition of flavonol glucosides in onion (Allium cepa). J. Agric. Food Chem. 1997, 45, 938-942. [CrossRef]

42. Sohaib, M.; Butt, M.S.; Anjum, F.M.; Khan, M.I.; Shahid, M. Augmentation of Oxidative Stability, Descriptive Sensory Attributes and Quality of Meat Nuggets from Broilers by Dietary Quercetin and ALPHA-Tocopherol Regimens. J. Food Process. Preserv. 2015, 40, 373-385. [CrossRef]

43. Berri, C.; Debut, M.; Santé-Lhoutellier, V.; Arnould, C.; Boutten, B.; Sellier, N.; Baéza, E.; Jehl, N.; Jégo, Y.; Duclos, M.; et al. Variations in chicken breast meat quality: Implications of struggle and muscle glycogen content at death. Br. Poult. Sci. 2005, 46, 572-579. [CrossRef] [PubMed]

44. De Oliveira, T.L.C.; de Carvalho, S.M.; de Araújo Soares, R.; Andrade, M.A.; das Graças Cardoso, M.; Ramos, E.M.; Piccoli, R.H. Antioxidant effects of Satureja montana L. essential oil on TBARS and color of mortadella-type sausages formulated with different levels of sodium nitrite. LWT 2012, 45, 204-212. [CrossRef]

45. Bourne, M.C. Texture Measurement of Individual Cooked Dry Beans By The Puncture Test. J. Food Sci. 1972, 37, 751-753. [CrossRef]

46. Estévez, M.; Ventanas, S.; Cava, R. Effect of natural and synthetic antioxidants on protein oxidation and colour and texture changes in refrigerated stored porcine liver pâté. Meat Sci. 2006, 74, 396-403. [CrossRef]

47. Arshad, M.S.; Anjum, F.M.; Khan, M.I.; Shahid, M.; Akhtar, S.; Sohaib, M. Wheat germ oil enrichment in broiler feed with $\alpha$-lipoic acid to enhance the antioxidant potential and lipid stability of meat. Lipids Health Dis. 2013, 12, 164. [CrossRef] [PubMed]

48. Hwang, K.-E.; Choi, Y.-S.; Choi, S.-M.; Kim, H.-W.; Choi, J.-H.; Lee, M.-A.; Kim, C.-J. Antioxidant action of ganghwayakssuk (Artemisia princeps Pamp.) in combination with ascorbic acid to increase the shelf life in raw and deep fried chicken nuggets. Meat Sci. 2013, 95, 593-602. [CrossRef] [PubMed]

49. Fernandez-Lopez, J.; Sayas-Barberá, E.; Muñoz, T.; Sendra, E.; Navarro, C.; Pérez-Alvarez, J.A. Effect of packaging conditions on shelf-life of ostrich steaks. Meat Sci. 2008, 78, 143-152. [CrossRef] 